\title{
Robotic Low Anterior Resection and TAH+BSO with Transvaginal NOSE
}

\section{Robotik Low Anterior Rezeksiyon'la Birlikte TAH+BSO ve Vaginal Yoldan NOSE}

\author{
๑ Neşet Köksal1,2, ๑ Ömer Faruk Özkan³, ๑ Ethem Ünal4, ๑ İsmail Kabak5, ๑ Muhammed Taha Demirpolat5, \\ (D) Gürkan Kıran6 \\ ${ }^{1}$ Yeditepe University Faculty of Medicine, Department of General Surgery, İstanbul, Turkey \\ ${ }^{2}$ Koşuyolu İhtisas Hospital, Clinic of General Surgery, İstanbul, Turkey \\ 3Çanakkale Onsekiz Mart University Faculty of Medicine, Department of General Surgery, Çanakkale, Turkey \\ 4University of Health Sciences Turkey, Sancaktepe Training and Research Hospital, Clinic of General Surgery, İstanbul, Turkey \\ 5University of Health Sciences Turkey, Ümraniye Training and Research Hospital, Clinic of General Surgery, İstanbul, Turkey \\ ${ }^{6}$ Bezmialem Vakıf University Faculty of Medicine, Department of Gynecology and Obstetrics, İstanbul, Turkey
}

\begin{abstract}
IIIIIIIII ABSTRACT
In the last century, laparoscopic interventions have been developed to minimize the somatic and phsiological effects of surgery. Laparoscopic approaches have become frequently used in colorectal surgery as well. In recent years, robotic surgery has become a recommended practice in rectum surgeries, especially due to better visualisation of the pelvis. In addition to providing a comfortable view in the pelvis, robotic surgery also provides the surgeon with the ability to perform the surgery under three-dimensional view and superior maneuverability in the narrow pelvis. Additionally removing of the specimen via natural ways, that is, transanal, transvaginal, or transgastric, without creating an incision in the abdomen during laparoscopic procedures has gained attention. This approach is called natural orifice specimen extraction (NOSE) and it has been used with increasing frequency in recent years as a preferred method in experienced centers. However, data on NOSE application in robotic rectum surgery is limited, and in this video presentation, we aimed to present a patient who underwent robotic low anterior resection and total hysterectomy for rectum cancer, in which the entire specimen was removed transvaginally (NOSE).
\end{abstract}

Keywords: NOSE, rectum cancer, robotic LAR

\section{|IIIIIII| ÖZ}

Cerrahinin somatik ve fizyolojik etkilerini minimalize etmek için son yüzyılda laparoskopik girişimler çok fazla ön plana çıkmıştır. Kolorektal cerrahidede laparoskopik yaklaşımlar sıklıkla tercih edilir hale gelmiştir. Son yıllarda ise robotik cerrahide özellikle pelviste daha iyi görüş sağlaması nedeniyle rektum ameliyatlarında önerilen bir uygulama haline gelmiştir. Robotik cerrahinin pelviste konforlu bir görüş sağlaması dışında, cerrah açısındanda üç boyutlu görüntü altında ameliyatı gerçekleştirmesi ve robotun dar pelviste manevra kabiliyetide diğer avantajlarıdır. Bunun dışında laparoskopik cerrahi uygulamalarında spesimenin çıkarılması için abdomende kesi oluşturmak yerine doğal yollar yani spesimenin transanal, transvajinal veya transgastrik olarak çıkarılması gündeme gelmiştir. Bu uygulama natural orifice specimen extraction (NOSE) olarak adlandırılmakla birlikte deneyimli merkezlerede tercih edilen bir yöntem olarak son yıllarda artan sıklıkla kullanılmaktadır. Ancak Robotik rektum cerrahisi ile beraber NOSE uygulaması ile ilgili veriler kısıtlı olup, bu video sunumda rektum kanseri için robotik low anterior rezeksiyon birlikte total histerektomi uygulanan hastada tüm speswimenin trans vajinal olarak çıkarıldığı (NOSE) olgunun video görüntüsü eşliğinde sunulması amaçlanmıştır.

Anahtar Kelimeler: NOSE, rektum kanseri, robotik LAR 


\section{Introduction}

There have been serious developments in the treatment of rectal cancer in the last century. In this process, both neoadjuvant use of radiotherapy and chemotherapeutics played an important role in addition to the definition of total mesorectal excision. In the last 20 years, although minimally invasive surgery has become widespread in the surgical treatment of benign and malignant diseases of the colon and rectum, controversies continue about the use of laparoscopic surgery in rectum cancer. There are studies showing that robotic surgery is superior to conventional laparoscopy in the surgery of rectum cancer with the developing technology. Robotic surgery has some advantages: The robotic arms can manipulate the pelvis more easily, the operation can be performed with three-dimensional images, the surgeon sits and does not reflect possible tremors to the surgery. It has some disadvantages: It can not be performed in every center and it has a high cost. Another development is the methods defined for the removal of the resected specimen. At this point, the specimen is removed via transanal or transvaginal route, that is, without making a new incision in the abdomen. It is reported that this method, called NOSE, provides benefits to the patient in terms of postoperative pain and wound healing. ${ }^{1,2}$

In the colonoscopy of a 60-year-old female patient, a polyp with a size of $1.5 \mathrm{~cm}$ was detected in the middle rectum, and polypectomy was performed. After histopathological examination showed the presence of adenocarcinoma, an magnetic resonance imaging was performed and no additional pathology was detected in the uterus, except for a myoma uteri with a size of $6.5 \mathrm{~cm}$. The patient was discussed in the multidisciplinary council and the surgical decision was made. After obtaining the consent form, she was taken to surgery. The ports were placed in accordance with the Da Vinci Xi robotic system in a standard way and the hysterectomy procedure following docking was completed robotically by the obstetrics team and the specimen was taken out of the vagina. The low anterior resection procedure was completed robotically by placing a tampon in the vagina. The tampon was removed from the vagina and the rectum specimen was taken out of the abdomen from the vagina. Following the control of the anastomosis with indocyanine green, an ileostomy was opened in the right lower quadrant and the surgery was terminated. Histopathological examination of the specimen was reported as $\mathrm{T} 1 \mathrm{~N} 1$.

As a result, although it has a disadvantage in terms of cost, the robotic method and the NOSE method in appropriate patients are the preferred method for the patient and the surgeon.

Informed Consent: After obtaining the consent form, she was taken to surgery.

Peer-review: Externally and internally peer reviewed.

\section{Authorship Contributions}

Concept: N.K., Ö.F.Ö., E.Ü., İ.K., M.T.D., G.K., Design: N.K., Ö.F.Ö., E.Ü., İ.K., M.T.D., G.K., Data Collection or Processing: N.K., Ö.F.Ö., E.Ü., İ.K., M.T.D., G.K., Analysis or Interpretation: N.K., Ö.F.Ö., E.Ü., İ.K., M.T.D., G.K., Literature Search: N.K., Ö.F.Ö., E.Ü., İ.K., M.T.D., G.K., Writing: N.K., Ö.F.Ö., E.Ü., İ.K., M.T.D., G.K.

Conflict of Interest: No conflict of interest was declared by the authors.

Financial Disclosure: The authors declared that this study received no financial support.

\section{References}

1. Jones K, Qassem MG, Sains P, Baig MK, Sajid MS. Robotic total meso-rectal excision for rectal cancer: A systematic review following the publication of the ROLARR trial. World J Gastrointest Oncol 2018;10:449-464.

2. Hida K, Okamura R, Sakai Y, Konishi T, Akagi T, Yamaguchi T, Akiyoshi T, Fukuda M, Yamamoto S, Yamamoto M, Nishigori T, Kawada K, Hasegawa S, Morita S, Watanabe M. Open versus laparoscopic surgery for advanced low rectal cancer: a large, multicenter, propensity score matched cohort study in Japan Ann Surg 2018;268:318-324.

\section{Video 3.}

https://www.doi.org/10.4274/tjcd.galenos.2020.2020-10-9.video3 